\title{
Halogenation of Unactivated Carbon Centers in Natural Product Biosynthesis: Trichlorination of Leucine during Barbamide Biosynthesis
}

\author{
Danica P. Galonić, Frédéric H. Vaillancourt, ${ }^{\dagger}$ and Christopher T. Walsh* \\ Department of Biological Chemistry and Molecular Pharmacology, \\ Harvard Medical School, Boston MA 02115
}

\section{Supporting Information}

Chemical synthesis. All reactions were performed under a positive pressure of nitrogen. Organic solutions were concentrated by rotary evaporation below $30^{\circ} \mathrm{C}$ at ca. 25 Torr. Flash column chromatography was performed employing 230-400 mesh silica gel. Thin-layer chromatography was performed using glass plates pre-coated to a depth of $0.25 \mathrm{~mm}$ with $230-400$ mesh silica gel impregnated with a fluorescent indicator (254 $\mathrm{nm})$. NMR spectra were recorded on a Varian 200, Varian 500 and Varian $600 \mathrm{MHz}$ NMR spectrometers. Chemical shifts are expressed in parts per million ( $\delta$ scale) downfield from tetramethylsilane and are referenced to residual protium in the NMR solvent. Data are presented as follows: chemical shift, multiplicity ( $\mathrm{s}=$ singlet, $\mathrm{d}=$ doublet, $\mathrm{t}=$ triplet, $\mathrm{m}=$ multiplet and/or multiple resonances), and coupling constants in $\operatorname{Hertz}(\mathrm{Hz})$, and integration.

(2S,4S)-5-chloroleucine - TFA salt was prepared starting from (2S)- $N, N$-di-tertbutoxycarbonylamino-5-hydroxy-(4S)-methyl-pentanoic acid tert-butyl ester ${ }^{1}$ by a known procedure. ${ }^{2}$ Analytical data: ${ }^{1} \mathrm{H}$ NMR $\left(500 \mathrm{MHz}, \mathrm{D}_{2} \mathrm{O}\right): \delta=3.91(\mathrm{dd}, J=8.8,5.6 \mathrm{~Hz}$, $1 \mathrm{H}), 3.53(\mathrm{dd}, J=10.9,4.7 \mathrm{~Hz}, 1 \mathrm{H}), 3.45(\mathrm{dd}, J=10.9,5.3 \mathrm{~Hz}, 1 \mathrm{H}), 1.98-1.90(\mathrm{~m}, 2 \mathrm{H})$, 1.77 (ddd, $J=14.4,8.8,5.6 \mathrm{~Hz}, 1 \mathrm{H}), 0.95 \mathrm{ppm}(\mathrm{d}, J=6.8 \mathrm{~Hz}, 3 \mathrm{H}) ; 13 \mathrm{C}$ NMR $(150$ MHz): $\delta=52.4,50.0,35.5,32.0,16.4 \mathrm{ppm}$; LRMS (ESI) ${ }^{+}: \mathrm{m} / \mathrm{z}$ calcd for $\mathrm{C}_{6} \mathrm{H}_{13} \mathrm{ClNO}_{2}$ $[M+\mathrm{H}]^{+}: 166.1$; found 166.1 .

(2S,4S)-5,5-dichloroleucine - TFA salt was prepared according to the previously described procedure. ${ }^{1}$ Analytical data: ${ }^{1} \mathrm{H}$ NMR $\left(500 \mathrm{MHz}, \mathrm{D}_{2} \mathrm{O}\right): \delta=5.99(\mathrm{~d}, J=2.9$ $\mathrm{Hz}, 1 \mathrm{H}), 3.82(\mathrm{dd}, J=9.4,5.0 \mathrm{~Hz}, 1 \mathrm{H}), 2.27$ (m, 1H), 2.04 (ddd, $J=14.7,9.4,3.8 \mathrm{~Hz}$, $1 \mathrm{H}), 1.89$ (ddd, $J=14.7,9.4,5.0 \mathrm{~Hz}, 1 \mathrm{H}), 1.07 \mathrm{ppm}(\mathrm{d}, J=6.5 \mathrm{~Hz}, 3 \mathrm{H}) ;{ }^{13} \mathrm{C} \mathrm{NMR}(150$ $\left.\mathrm{MHz}, \mathrm{CD}_{3} \mathrm{OD}\right): \delta=171.0,77.9,51.1,40.3,33.7,13.7 \mathrm{ppm}$; LRMS (ESI) ${ }^{+}: \mathrm{m} / \mathrm{z}$ calcd for $\mathrm{C}_{6} \mathrm{H}_{12} \mathrm{Cl}_{2} \mathrm{NO}_{2}[M+\mathrm{H}]^{+}:$200.0; found 200.1.

(2S,4S)-5,5,5-trichloroleucine - HCl salt was prepared according to the previously described procedure. ${ }^{3}$ Analytical data: ${ }^{1} \mathrm{H}$ NMR $\left(600 \mathrm{MHz}, \mathrm{D}_{2} \mathrm{O}\right): \delta=3.88$ (dd, $J=10.6,3.8 \mathrm{~Hz}, 1 \mathrm{H}), 2.70(\mathrm{~m}, 1 \mathrm{H}), 2.38(\mathrm{~m}, 1 \mathrm{H}), 2.01$ (ddd, $J=14.4,10.3,4.1 \mathrm{~Hz}$,

\footnotetext{
$\dagger$ Present address: Boehringer Ingelheim (Canada) Ltd., Research and Development, Dept. of Biological Sciences, Laval, Qc, H7S 2G5, Canada
} 
1H), $1.30 \mathrm{ppm}(\mathrm{d}, J=6.5 \mathrm{~Hz}, 3 \mathrm{H}) ;{ }^{13} \mathrm{C}$ NMR (150 MHz, $\left.\mathrm{CD}_{3} \mathrm{OD}\right): \delta=104.8,51.4,34.6$, 15.5 ppm; LRMS (ESI) ${ }^{+}: \mathrm{m} / \mathrm{z}$ calcd for $\mathrm{C}_{6} \mathrm{H}_{11} \mathrm{Cl}_{3} \mathrm{NO}_{2}[M+\mathrm{H}]^{+}:$:234.0; found 233.9.

Strains, media and growth. Escherichia coli Top10 (Invitrogen) was used for DNA propagation. E. coli BL21 (DE3) (Invitrogen) transformed with derivatives of pET28b (Novagen) was used for overexpression in Luria-Bertani (LB) medium.

Construction of plasmids and overexpression of proteins. The synthetic barA, barB1, barB2 and barD genes with optimal codons for overexpression in E. coli were purchased from DNA 2.0 (Menlo Park, CA). All 4 genes contained a NdeI site overlapping with the ATG start codon and an EcoRI site after the stop codon. The synthetic bar genes were cloned into pET28b (Novagen) using NdeI and EcoRI to yield the different expression plasmids. His-tagged Bar proteins were overexpressed in E. coli BL21(DE3) transformed with their respective plasmids. Two-liter cultures containing kanamycin $(50 \mu \mathrm{g} / \mathrm{mL})$ were inoculated with $20 \mathrm{~mL}$ of an overnight culture grown at 37 ${ }^{\circ} \mathrm{C}$. The cultures were incubated at $35{ }^{\circ} \mathrm{C}$ for $\sim 3 \mathrm{~h}$, then $25{ }^{\circ} \mathrm{C}$ for $\sim 30 \mathrm{~min}$, and then cooled to $15{ }^{\circ} \mathrm{C}$ prior to the addition of isopropyl- $\beta$-D-galactopyranoside to a final concentration of $0.5 \mathrm{mM}$. The cultures where incubated for another $16-17 \mathrm{~h}$, then harvested.

Protein Purification. All buffers were prepared using water purified on a Milli-Q Water System to a resistance greater that $17 \mathrm{M} \Omega \cdot \mathrm{cm}$. For BarA and BarD proteins, cell pellets from $6 \mathrm{~L}$ of culture were resuspended in buffer A $(20 \mathrm{mM}$ HEPPS pH 8.0, 300 $\mathrm{mM} \mathrm{NaCl}, 5 \mathrm{mM}$ imidazole). The cells were disrupted by two successive passes through a French press operated at 12,500 psi at $4{ }^{\circ} \mathrm{C}$. The cell debris was removed by centrifugation at $27,000 \mathrm{~g}$ for $30 \mathrm{~min}$. The supernatant was carefully removed. This "raw extract" was incubated with $4 \mathrm{~mL}$ of Ni-NTA agarose resin (Qiagen) for $1 \mathrm{~h}$, and poured in a low pressure chromatography column $(1.5 \mathrm{~cm}$ diameter; Bio-Rad). The resin was washed successively with 5 column volumes of buffer $A$ and 4 column volumes of buffer $\mathrm{B}$ (20 mM HEPPS pH 8.0, $300 \mathrm{mM} \mathrm{NaCl}, 30 \mathrm{mM}$ imidazole) to remove non-specifically bound contaminants. The proteins were eluted using buffer $\mathrm{C}(20 \mathrm{mM}$ HEPPS $\mathrm{pH} 8.0$, $100 \mathrm{mM} \mathrm{NaCl}, 200 \mathrm{mM}$ imidazole). The elutes were concentrated to $\sim 10 \mathrm{~mL}$ using Amicon Ultra centrifugal devices (Millipore) and desalted on a Bio-Gel P-6 DG desalting gel (for BarD) or a Bio-Gel P-2 DG desalting gel (for BarA; both gels from Bio Rad), both equilibrated in buffer $\mathrm{D}(20 \mathrm{mM}$ Hepes $\mathrm{pH} 7.5)$. The protein were eluted in the same buffer, fractions pooled, concentrated, flash-frozen in liquid $\mathrm{N}_{2}$ in $25-50 \mu \mathrm{L}$ aliquots, and stored at $-80{ }^{\circ} \mathrm{C}$ until further use.

For BarB1 and BarB2, all cell-free preparations were manipulated under an inert atmosphere using an Mbraun Labmaster glovebox (Stratham, NH) maintained at $2 \mathrm{ppm}$ $\mathrm{O}_{2}$ or less. Chromatography was performed by using an ÄKTA Explorer 100 (GE Healthcare) configured to maintain an anaerobic atmosphere during purification. ${ }^{4}$ Buffers were sparged with argon, and equilibrated in the glove box for $24 \mathrm{~h}$ before use. Cell pellets from $6 \mathrm{~L}$ of cultures were resuspended and subjected to the French press as described for BarA and BarD. The broken cells were then sparged with argon for 20 min before transfer in gas-tight tubes in the glove box and centrifuged at 27,000 $\mathrm{g}$ for $30 \mathrm{~min}$. The supernatant was loaded on Ni-NTA agarose resin column as described previously, 
except that all manipulations were performed in the glove box. The Ni-NTA eluants were concentrated by using Amicon stirred ultrafiltration cells (Millipore) under $\mathrm{N}_{2}$ pressure and desalted on a Bio-Gel P-6 DG desalting gel equilibrated in buffer E (20 mM HEPPS $\mathrm{pH} 8.0,80 \mathrm{mM} \mathrm{NaCl}$ ). The proteins were eluted in the same buffer and fractions containing proteins pooled. The protein samples were then adjusted to $2 \mathrm{mM} \mathrm{CaCl}_{2}$, and incubated with thrombin (1U:10 mg, thrombin:BarB proteins) for $3 \mathrm{~h}$ at $19{ }^{\circ} \mathrm{C}$. The samples were then injected on a 26/60 Superdex 75 column equilibrated in buffer $\mathrm{F}$ (20 $\mathrm{mM}$ Hepes $\mathrm{pH} 7.5,80 \mathrm{mM} \mathrm{NaCl}$ ). Both BarB1 and BarB2 eluted as monomers. Protein concentrations were determined by the Bradford method. ${ }^{5}$

In Vitro Reconstitution of BarB1 and BarB2. Apo-BarB proteins were reconstituted anaerobically by incubation with $2 \mathrm{mM}$ DTT, $2 \mathrm{mM} \alpha$-ketoglutarate, and 1 $\mathrm{mM} \mathrm{Fe}\left(\mathrm{NH}_{4}\right)_{2}\left(\mathrm{SO}_{4}\right)_{2}$ for 10 min before desalting on a Bio-Gel P-6 DG column equilibrated in buffer F. Fractions containing proteins were pooled, concentrated in Amicon stirred ultrafiltration cells (Millipore) under $\mathrm{N}_{2}$ pressure flash-frozen in liquid $\mathrm{N}_{2}$ in $25 \mu \mathrm{L}$ aliquots, and stored at $-80{ }^{\circ} \mathrm{C}$ until further use. Iron concentrations were determined colorimetrically by using FERENE S. ${ }^{6}$

Priming of BarA and Halogenase Activity Assays. Posttranslational modification of the apo-BarA ( $\mathrm{T}$ domain) with the phosphopantetheinyl group was performed with the Sfp protein. ${ }^{7}$ BarA $(100 \mu \mathrm{M})$ was incubated with CoA $(200 \mu \mathrm{M})$, $\mathrm{MgCl}_{2}(2 \mathrm{mM})$, BarD $(20 \mu \mathrm{M})$ and Sfp $(2.5 \mu \mathrm{M})$ in $20 \mathrm{mM}$ Hepes pH 7.5 for $40 \mathrm{~min}$ at room temperature prior to the amino acid loading. Subsequently, L-Leu solution prepared by mixing $5.8 \mu \mathrm{L}$ of $50 \mathrm{mM}$ L-Leu and $140 \mu \mathrm{L}$ of L-[ $\left.{ }^{14} \mathrm{C}\right] \mathrm{Leu} 331 \mathrm{mCi} / \mathrm{mmol}$ was added to a final concentration of $2 \mathrm{mM}$, followed by ATP (final concentration $2 \mathrm{mM}$ ). Assay mixtures were incubated for $60 \mathrm{~min}$ at room temperature. Following incubation, $\alpha-$ ketoglutarate (final concentration $2 \mathrm{mM}$ ) and BarB1 and/or BarB2 were added (final concentration of each of halogenating enzymes $40 \mu \mathrm{M}$ ). Samples were incubated for $1 \mathrm{~h}$ at room temperature (note: for the sample described in Figure 1Ae incubation with BarB2 was carried out for $1 \mathrm{~h}$, at which point BarB1 was added and incubation continued for an additional hour). Assay mixtures were transferred to $0.5 \mathrm{~mL}$ Ultrafree centrifugal devices equipped with a $10 \mathrm{kDa}$ membranes (Millipore). Excess amino acids were removed by using four wash steps with $0.4 \mathrm{~mL}$ of $20 \mathrm{mM}$ Hepes $\mathrm{pH}$ 7.5. The resulting protein solution was diluted to $150 \mu \mathrm{L}$ with $20 \mathrm{mM}$ Hepes $\mathrm{pH} 7.5$, and incubated with $5 \mu \mathrm{M}$ type II thioesterase TycF to release the loaded amino acid. ${ }^{8}$ The amino acids were separated from the proteins by centrifuging the filter devices. The amino acids were then derivatized with $O$-phthalaldehyde and 3-mercaptopropionic acid $^{9}$ and analyzed by comparison with authentic standards on a Beckman System Gold HPLC equipped with $\beta$ RAM Model 3 radioisotope detector and model $168 \mathrm{UV}$ Detector $(\lambda=338 \mathrm{~nm})$. The following HPLC conditions were used: Gradient 25-75\% B over $25 \min$ (A: $40 \mathrm{mM}$ $\mathrm{Na}_{2} \mathrm{HPO}_{4} \mathrm{pH}$ 7.8; B: $\mathrm{CH}_{3} \mathrm{CN}: \mathrm{MeOH}: \mathrm{H}_{2} \mathrm{O}=45: 45: 10$ ); Column: Phenomenex Luna $5 \mu$ C18 $100 \AA$, $250 \times 4.5 \mathrm{~mm}$. Comparison of the retention time of trichloroleucine-OPA derivative obtained via derivatization of enzymatic product and synthetic $(2 S, 4 S)-5,5,5-$ trichloroleucine and $(2 R, 4 S)-5,5,5$-trichloroleucine revealed that enzymatic products has identical retention time only with $(2 S, 4 S)$ diastereoisomer, while its retention time differs 
by $0.4 \mathrm{~min}$ from $(2 R, 4 S)$ diastereoisomer, indicating good separation of various trichloroleucine derivatives with employed HPLC conditions.

Loading of $(2 S, 4 S)$-5-Chloroleucine and (2S,4S)-5,5-Dichloroleucine and Halogenase Activity Assays. BarA $(100 \mu \mathrm{M})$ was incubated with $\mathrm{CoA}(200 \mu \mathrm{M}), \mathrm{MgCl}_{2}$ $(2 \mathrm{mM})$, BarD $(40 \mu \mathrm{M})$ and Sfp $(2.5 \mu \mathrm{M})$ in $20 \mathrm{mM}$ Hepes $\mathrm{pH} 7.5$ for $1 \mathrm{~h}$ at room temperature prior to the amino acid loading. Subsequently, either $(2 S, 4 S)$-5-chloroleucine or $(2 S, 4 S)-5,5$-dichloroleucine were added to a final concentration of $4 \mathrm{mM}$, followed by ATP (final concentration $4 \mathrm{mM}$ ). Assay mixtures were incubated for $1 \mathrm{~h}$ at room temperature. Following incubation, BarB1 or BarB2 (final concentration of each of halogenating enzymes $40 \mu \mathrm{M}$ ) and $\alpha$-ketoglutarate (final concentration $2 \mathrm{mM}$ ) were added. All assays were performed in triplicates. Samples were incubated for $1 \mathrm{~h}$ at room temperature, triplicates of assays were transferred together to $0.5 \mathrm{~mL}$ Ultrafree centrifugal devices equipped with a $10 \mathrm{kDa}$ membranes (Millipore), excess of amino acids was removed, and bound amino acids were released from BarA as previously described. The amino acids were then derivatized with o-phthalaldehyde and 3mercaptopropionic acid and analyzed by comparison with authentic standards on a Beckman System Gold HPLC equipped with Model 168 UV Detector $(\lambda=338 \mathrm{~nm})$ under the same HPLC conditions.

For all activity assays with BarA loaded with either L-Leu, mono- and dichloroleucine, control experiments were carried out in the absence of halogenating enzymes. Under these conditions, no change in structure of loaded amino acid was observed after the same incubation, release and derivatization procedure.

\footnotetext{
${ }^{1}$ Ardá, A.; Jiménez, C.; Rodríguez, J. Tetrahedron Lett. 2004, 45, 3241-3243.

${ }^{2}$ Gerwick, W. H.; Leslie, P.; Long, C. C.; Marquez, B. L.; Willis, C. L. Tetrahedron Lett. 2003, 44, 285288.

${ }^{3}$ Sitachitta, N.; Márquez, B. L.; Williamson, R. T.; Rossi, J.; Roberts, M. A.; Gerwick, W. H.; Nguyen, V.A.; Willis, C. L. Tetrahedron 2000, 56, 9103-9113.

${ }^{4}$ Vaillancourt, F. H.; Han, S.; Fortin, P. D.; Bolin, J. T.; Eltis, L. D. J. Biol.Chem. 1998, 273, 3488734895 .

${ }^{5}$ Bradford, M. M. Anal. Biochem. 1976, 72, 248-254.

${ }^{6}$ Haigler, B. E.; Gibson, D. T. J. Bacteriol. 1990, 172, 457-464.

${ }^{7}$ Quadri, L. E. ; Weinreb, P. H. ; Lei, M. ; Nakano, M. M. ; Zuber, P. ; Walsh, C. T. Biochemistry 1998, 37, $1585-1595$.

${ }^{8}$ Yeh, E.; Kohli, R. M.; Bruner, S. D.; Walsh, C. T. ChemBioChem. 2004, 5, 1290-1293.

${ }^{9}$ Molnar-Perl I. J. Chromatogr. A 2001, 913, 283-302.
} 